УДК 159.942

https://doi.org/10.52058/2786-4952 -2021-4(4)-25-33

Havran Maryana Ivanivna Candidate of Pedagogical Sciences, associate professor, associate professor of Foreign Languages Department, Lviv Polytechnic National University, S. Bandera St., 12, Lviv, 79000, tel.: (067) 258-66-68, e-mail: Mariana.i.havran@lpnu.ua, https://orcid.org/0000-0003-1345-9235

Svatiuk Oksana Robertivna Candidate of Economical Sciences, associate professor, associate professor of Human Resource Management and Administration Department, Lviv Polytechnic National University, S. Bandera St., 12, Lviv, 79000, тел.: (0322) 58-21-11, e-mail: Oksana.r.svatiuk@lpnu.ua, https://orcid.org/0000-0003-0099-2532

\title{
TEACHING EMOTIONAL INTELLIGENCE TO STUDENTS OBTAINING BACHELOR'S DEGREE IN MANAGEMENT
}

\begin{abstract}
The article deals with identifying and analyzing ways of improving emotional intelligence of students obtaining Bachelor's degree in Management in Ukrainian higher education institutions. Emotional intelligence is defined as a separate psychological phenomenon which is of primary importance in the development of highly qualified and successful employees. It is proved that emotional intelligence is one of the key factors in the managers' endeavour to become successful administrators and competitive specialists. Considering research papers of foreign and Ukrainian scientists it is stated that emotional intelligence should be an integral part of the training programme of managers obtaining Bachelor's degree. Several ways of providing students with emotional competences and increase their awareness emotional intelligence are regarded and thoroughly analyzed. In the context of updating and modernizing educational process in Ukrainian higher education institutions it is recommended to make Fundamentals of Psychology and Pedagogy course compulsory, to focus students' attention on their emotional development while teaching professional majors, to apply different teaching methods and techniques directed on practicing students' emotions control and developing their emotional competences while teaching foreign languages courses. Emotional Intelligence in Management course is considered as one of the most essential way of teaching emotional intelligence to students in Management. The structure and main outcomes of the discipline have been presented; the main skills which can be achieved and developed in the process of studying this course have been outlined. The conclusion suggests that higher education institutions of Ukraine where students can obtain Bachelor's degree in Management have to provide them with full training in emotional intelligence to facilitate their academic and personal success, their career growth.
\end{abstract}


Журнал«Герспективитаінновації науки»

(Серія«Гедагогіка», Серія«Гцихологія», Серія«Медицинв»

№4(4) 2021

Keywords: emotional intelligence, competences, students, improving emotional intelligence, training programme, Bachelor's degree in Management.

Гавран Мар'яна Іванівна кандидат педагогічних наук, доцент, доцент кафедри іноземних мов, Національний університет «Львівська політехніка», вул. С. Бандери, 12, Львів, 79000, тел.: (067) 258-66-68, e-mail: Mariana.i.havran@1pnu.ua, https://orcid.org/0000-0003-1345-9235

Сватюк Оксана Робертівна кандидат економічних наук, доцент, доцент кафедри менеджменту персоналу та адміністрування, Національний університет «Львівська політехніка», вул. С. Бандери, 12, Львів, 79000, тел.: (0322) 58-21-11, e-mail: Oksana.r.svatiuk@lpnu.ua, https://orcid.org/0000-0003-0099-2532

\section{НАВЧАННЯ ЕМОЦИЙНОГО ІНТЕЛЕКТУ СТУДЕНТІВ, ЯКІ ЗДОБУВАЮТЬ СТУПЕНЬ БАКАЛАВРА 3 МЕНЕДЖМЕНТУ}

Анотація. У статті здійснено вивчення та наліз шляхів підвищення емоційного інтелекту студентів, які здобувають ступінь бакалавра за спеціальністю «Менеджмент» у вищих навчальних закладах України. Емоційний інтелект визначено як окремий психологічний феномен, що має одне 3 першочергових значень у розвитку висококваліфікованих та успішних працівників. Доведено, що емоційний інтелект є одним із ключових факторів у прагненні менеджерів стати успішними адміністраторами та конкурентоспроможними спеціалістами, емоційна стабільність, контроль і обізнаність є інколи більш важливими, ніж самі знання. Вивчаючи дослідження зарубіжних та українських науковців, виявлено, що емоційний інтелект має бути невід'ємною частиною програми підготовки менеджерів, які здобувають ступінь бакалавра. Розглянуто та детально проаналізовано декілька способів надання студентам емоційних компетенцій та підвищення їхньої усвідомленості емоційного інтелекту. У контексті оновлення та модернізації навчального процесу в українських вищих навчальних закладах рекомендується зробити курс «Основи психології та педагогіки» обов'язковим; зосередити увагу студентів на їх емоційному розвитку під час навчання фахових дисциплін; під час викладання дисциплін, спрямованих на вивчення іноземних мов, застосовувати різні методи та методики навчання, спрямовані на розвиток вміння контролювати особисті емоції та інших, удосконалення емоційних компетенцій студентів. Курс «Емоційний інтелект менеджера» вважається одним із найважливіших способів навчання емоційному інтелекту студентів, які здобувають ступінь бакалавра 3 менеджменту. Представлено структуру, основні теми, результати навчання цієї дисципліни. У висновку зазначено, що вищі навчальні заклади України, де студенти можуть отримати ступінь бакалавра 3 менеджменту, мають забезпечити їх повноцінною підготовкою з питань емоційного інтелекту, щоб 
сприяти їх академічному та особистому успіху, кар’єрному зростанню.

Ключові слова: емоційний інтелект, компетенції, студенти, вдосконалення емоційного інтелекту, навчальна програма, ступінь бакалавра з менеджменту.

Introduction. Current society is facing with new challenges caused by rapid development of knowledge, information technologies, international opportunities and global issues. Therefore, one of the tasks of higher education institutions (HEIS) is to offer comprehensive training for students, who should be equipped not only by necessary professional or tech skills but also have a wide range of soft skills, which lead to a successful professional path.

Today, scientists emphasize the harmonious combination of intelligence and human emotions. In the process of analyzing the theoretical and methodological foundations of the emotional state of people and their intelligence, a close relationship between these concepts was established. It allows us to define emotional intelligence as a separate psychological phenomenon which is of primary importance in the development of highly qualified and successful employees.

The topicality of the article is obvious as bachelors in Management need to be aware of emotional intelligence, its components, physiological bases of emotions and feelings and their influence on personal lives, professional activities and success in the context of growing globalised and local business challenges.

Analysis of the recent research. Every year the interest of foreign and national scientists in the study of emotional intelligence (EI), also known as emotional quotient (EQ) along with investigating means of its formation and developing effective practices for improving emotional competencies is growing. Thus, theoretical and methodological foundations of emotional intelligence are presented in the works of foreign psychologists and educators Goleman D., Caruso D., Blum S., Salovey P., Mayer J., Christopher D. Connors, Grandapas R., Corgnet B., Gaechter S., González R.H. and many others. The issues of the development and improvement of students' emotional intelligence have got scientific attention of the Ukrainian and foreign researchers, such as: Dubovyk S., Drabchuk T., Nosenko E., Rosales-Pérez, A.M., Fernández-Gámez, M.A.

A detailed analysis of scientific, theoretical and practical works shows that foreign HEIs have accumulated considerable experience and progressive ideas in developing EI, effective leadership, successful businessmen and managers that can be a basis for modernizing the training system of business students in Ukrainian HEIs.

The purpose of the article is to analyze ways of teaching emotional intelligence to students obtaining Bachelor's degree in Management in Ukrainian HEIs.

Resuts. Since the end of the twentieth century, the concept of emotional intelligence is actively studied and improved by many foreign scientists, especially psychologists. Salovey P. and J. Mayer [1] assert that emotional intelligence is more responsible for success in life and learning than human IQ. Ukrainian scientists Dubovyk S. and Drabchuk T. regard emotional intelligence as a person's ability to 
interpret their own emotions and the emotions of those around them in order to use the information to achieve their goals [2, c. 3]. In this case, EQ is a system of cognitive abilities (sensation, perception, memory, thinking, all mental knowledge and skills). Moreover, American psychologist D. Goleman singles out twenty-five emotional competencies, among which there are self-knowledge, self-confidence, self-control, orientation on achievements, socialization, etc. [3].

In general, emotional intelligence is considered as an integrated concept that combines the ability to control personal emotional state, understand the emotional reactions and feelings of others, do not lose the ability to think in a stressful situation, choose adequate ways to communicate and solve problems. As a result, a lot of foreign research works began to support the relevance and integration of this notion into such areas as the relationships, workplace, child rearing, and personal fulfilment and development [4, p. 37].

The concept of emotional intelligence is actively applied not only in psychology or education, but also in management and administration. D. Goleman argues that emotional intelligence plays an important role in increasing the managerial effectiveness [5], as the success of any activity is only 33\% determined by technical skills and knowledge, and 67\% - by emotional competence. And for managers of different levels, these figures differ even more: only 15\% depends on IQ, and accordingly $85 \%$ is emotional intelligence. Foreign scientists agree [6] that HEIs should be aware of providing financial and business students with full emotional intelligence and even personality traits training to help them successfully tackle their professional future.

It is obvious that one of the key factors in the managers' endeavour to become successful administrators and competitive specialists is emotional intelligence. In today's conditions of growing competition in the labour market, when preference is given to those specialists who not only have intellectual abilities, but are also characterized by their emotional awareness and stability, the role of EI is increasing as never before.

Today, the training of bachelor students in Management is conducted in Ukrainian HEIs according to Management and Administration field of knowledge. To obtain a Bachelor's degree, it is necessary to achieve key learning outcomes, which are divided into four groups: 1) subject knowledge, 2) cognitive skills, 3) practical skills, 4) general skills [7]. As a result, the future manager acquires general and professional competencies that ensure his ability to carry out professional activities and production functions in the primary position immediately after graduation.

A Bachelor programme of management teaches students to be leaders in businesses, non-governmental and governmental organizations and agencies. To give management students full awareness in understanding organization, operations, administration of the organization with further responding to its goals, most of the training programmes include aspects of economics, business administration, and sociology. Additionally, students are provided with professional and soft skills to 
motivate, communicate, inspire, manage and think strategically in order to meet organization's goals. It is obvious that one of the main functions of a manager is to motivate his subordinates to successfully perform set tasks; it will be much easier to achieve if a manager creates a favourable emotional environment in the organization.

In this context, we agree with a statement [4, 38] that teaching emotional intelligence should play an important role and has a necessary place in the curricula of business schools, even more necessary than the undue emphasis which is upon academic rigor, technical or research competency. Studies also verify [8] that emotional intelligence can be taught to students; moreover, increased emotional intelligence predicts better learning outcomes. For instance, students on probation, who participated in workshops based on development of emotional intelligence skills, had a retention rate $20 \%$ higher than those who did not.

So, in our opinion development of emotional intelligence and its improvement should become an integral part of the training programme of managers along with developing professional skills and competences in their major subjects. Emotional intelligence is often improved and developed with age, as well as in the process of professional development. However, because of managers' professional activities their level of EQ must be well developed even before starting their career path.

According to Management curriculum offered by Ukrainian HEIs, for example, in Lviv National Polytechnic University, students are able to choose among optional subjects - Fundamentals of Psychology and Pedagogy. The content of this discipline includes the study of mental health, socialization, psychological and pedagogical aspects of education, upbringing and personal development, psychology and pedagogy of the family, and so on. Along with them students learn such topics as: "Emotional sphere, emotional states, tension and its impact on productivity", "Groups and types of management", "Ways to improve the effectiveness of group activities", "Psychological and pedagogical aspects of communication", "Spontaneous socio-psychological phenomena in collective activity', etc. [7]. However, only 24 classroom hours are devoted to mastering such interesting and necessary notions and topics in psychology which can be really essential in improving emotional intelligence of managers.

One of the approaches in improving EQ is using different psychological tests, personal questionnaires, and interpersonal communication in major subjects, which are able to increase students' awareness in emotional intelligence. For example, it is possible to apply various communicative methods and techniques, questionnaires, tests during teaching such subjects as Foreign Language for Specific Purposes or Business Foreign Language, where teachers can involve students in general and group discussions, debates, making dialogues, case studies, allowing them to express their own opinions, prove their ideas, simulate and solve various business problems and professional situation. In general, such activities help to develop communication, negotiation, decision-making skills, and non-verbal means of communication, increasing their interpersonal and emotional awareness.

There are different strategies that can be focused on students' emotional 
intelligence self-development, among them scientists identify: 1) strategies for developing emotional self-perception; 2) strategies for mastering the skills of managing their own emotions; 3) strategies for increasing social sensitivity; 4) strategies for mastering the skills of managing relationships with others [9, p. 38].

To achieve relationship management strategies in the process of learning any professional topics in foreign languages classes, teachers have to help students to comply with certain rules, among which the most essential are: 1) being open and curious; 2) improving the quality of natural communication style; 3 ) creating trustful communicative environment; 4) being purposeful; 5) being ready to recognize the feelings of other people; 6) identifying emotions of others in different situations; 7) feeling free to show your gratefulness to someone, if he/she deserves it; 8) explaining your decisions-making; 9) complying your intentions with your actions, and others.

We consider that one of the interesting ways to identify EI of students' obtaining Bachelor's degree in Management is to test students' emotional intelligence at the beginning of academic process and then at the final stage, that will determine the level of readiness of the future manager to understand interpersonal relationships, their competences to manage their own emotions and recognize others' in the process of communication and decision-making. For example, it can be a test created and proposed by N. Hall or the Global Emotional Intelligence Test based on Goleman's four quadrant model of emotional intelligence competency [10]. The letter includes 40 two-option questions - 10 for each quadrant, which includes reflecting your selfawareness, self-management, social-awareness and relationship management, among them there are questions really reflecting capability level of managing people and your emotional self-assessment.

We believe that for improving emotional intelligence of students obtaining Bachelor's degree in Management, it is not enough to give a short optional psychological and pedagogical training course, not even compulsory one, or simply use some techniques, separate topics or tests during studying major subjects. It is recommended to include a Manager's Emotional Intelligence course into the curriculum of the bachelor programme. Such practice has been successfully realized in management training programmes of foreign HEIs for the last decade. For example, at Quinnipiac University, Self-Management course is given for students, incorporating different Goleman's elements and John and Joyce Weir's model for self-differentiation and self-management [4]. This course is created to give students an opportunity to explore their own self-awareness and interpersonal awareness, necessary steps for behaviour, feeling states and belief system changes.

One of the important trends in improving students' emotional intelligence which can be applied in management programme at Ukrainian HEIs is Manager's Emotional Intelligence course. It consists of lectures and practical classes, including trainings, business games, and case studies. This discipline is designed according to the basic methodological principles, such as: relevance, individuality, differentiation, innovation, effectiveness, openness, variability, unity of requirements, 
interchangeability. Studying this discipline, students will be provided with presentation-based lectures, practical decision-making of real situations. Among the most important topics for learning can be: The concept of emotional creativity and emotional competence of managers, Strategies for self-development of emotional intelligence, Emotional intelligence of the leader, Managing the emotions of others, Methods of the development of emotional intelligence, Basic emotions management strategies, Self-motivation, Regulatory component of emotional intelligence, etc.

The outcomes of Manager's Emotional Intelligence course are: students' abilities to logically evaluate conflict and stressful situations, risks, and problems in businesses and offer the most effective measures and ways for their deciding in the context of applying practical experience; to realize the achieved knowledge and skills in preparing and making public speeches sharing the experience in developing and strengthening emotional intelligence using information and communication technologies.

Taking Manager's Emotional Intelligence course students of Management are considered to acquire necessary skills in carrying out effective communication in developing teamwork projects; making justified decisions to ensure the economic efficiency of enterprises, organizations, communities; working in a group or team, negotiate and influence other people opinions on professional issues; making presentations of scientific and practical matters and hold them in front of a public; coping with stressful situations and meet new challenges; realizing the need for lifelong learning in order to deepen the acquired professional knowledge and to acquire new hard and social skills; making decisions independently, to achieve the set goal in compliance with the requirements of professional ethics and moral codes. Manager's Emotional Intelligence course adopts a strong developmental approach whereby students get an opportunity to examine themselves and experience their individual development.

Conclusions. In the modern knowledge society, emotional intelligence has become an important study. While the competition between specialists in management is growing in the labour market, communication skills and the ability to manage emotions are becoming a driving force in their career. The study of emotional intelligence is gaining momentum in the context of modernizing training programmes in Management, as emotional competencies are sometimes even more important in managers' career growth than the level of their knowledge or intelligence.

Therefore, it is crucially important to improve managers' emotional intelligence while they are obtaining Bachelor's degree. In the context of updating and modernizing educational process in HEIs, one of the trends in improving students' EQ is to increase the number of academic hours in Fundamentals of Psychology and Pedagogy discipline and make it compulsory. Another important way toward improving EI is to focus students' attention on their emotional development while teaching professional majors. We mention also about different teaching methods and techniques which can be applied to practice controlling students' emotions and develop their emotional 
competences while teaching foreign languages courses. But Manager's Emotional Intelligence course is considered to be the most useful in HEIs' endeavour to provide profound knowledge and competences in EI to students in management.

We realize that the scientific problem under investigation include too many aspects to be thoroughly studied in one research paper, so further investigation based on the foreign experience in training techniques in developing EI of business students should be conducted.

\section{Jimepamypa:}

1. Salovey P., Mayer J. Emotional intelligence / P. Salovey, J. Mayer // Imagination, cognition, and personality, 9. - 1990. - Pp. $185-211$.

2. Дубовик С., Драбчук Т. Розвиток емоційного інтелекту сучасних менеджерів як умова їх успішної діяльності / С. Г. Дубовик, Т. І. Драбчук // Вісник Сумського національного аграрного університету. Серія «Економіка і менеджмент». - Випуск 5 (60). - 2014. - С. 1 - 7.

3. Goleman D. Working with emotional intelligence / D. Goleman // New York: Bantam, 1998.

4. Bellizzi F. Teaching emotional intelligence in the business school curriculum / F. Bellizzi // American Journal of Business Education. Third Quarter. Volume 1. Number 1. - 2008. - 37.

5. Гоулман Д. Эмоциональное лидерство. Искусство управления людьми на основе эмоционального интеллекта // Д. Гоулман, Р. Бояцис, Э. Макки. - М.: «Альпина Паблишер», 2015. - $301 \mathrm{c}$.

6. Fernández-Gámez M.A., Torroba-Díaz M., Molina-Gómez J. A. Study of the emotional intelligence and personality traits of university finance students / M.A. Fernández-Gámez, M. Torroba-Díaz, J. A. Molina-Gómez // Education Sciences. 2021. 11(1):25. DOI:10.3390/educsci11010025

7. Каталог освітніх послуг Львівської політехніки. Напрям підготовки «Менеджмент» [Електронний ресурс]. - Режим доступу: // http://edu.lp.edu.ua/napryamy/6030601-menedzhment

8. Ruel Ch. Teaching emotional intelligence to students / Ch. Ruel // Wiley. URL: https://www.wiley.com/network/instructors-students/teaching-strategies/teaching-emotionalintelligence-to-students

9. Носенко Е.Л., Четверик-Бурчак А.Г. Посібник до вивчення курсу «Теорія емоційного інтелекту» / Е.Л. Носенко, А.Г. Четверик-Бурчак. - Дніпропетровськ, 2014. - 73с.

10. Discover your level of EI. Global Leadership Foundation. URL: http://globalleadershipfoundation.com/geit/eitest.html

\section{References:}

1. Salovey, P. \& Mayer, J. (1990). Emotional intelligence. Imagination, cognition, and personality (9). (Pp. $185-211)$.

2. Dubovyk, S. \& Drabchuk, T. (2014). Rozvytok emotsiinoho intelektu suchasnykh menedzheriv yak umova yikh uspishnoi diialnosti [Development of emotional intelligence of modern managers as a condition of their successful activity]. Visnyk Sumskoho natsionalnoho ahrarnoho universytetu. Seriia «Ekonomika i menedzhment - Bulletin of Sumy National Agrarian University. Economics and Management Series (Vol 5 (60)) [in Ukrainian].

3. Goleman, D. (2008). Working with emotional intelligence. New York: Bantam.

4. Bellizzi, F. (2008). Teaching emotional intelligence in the business school curriculum. American Journal of Business Education. Third Quarter (Vol. 1 (1)).

5. Goleman, D., Boyatzis R., Makki E. (2015). Emotsyonalnoe lyderstvo. Iskustvo upravlenyia liudmy na osnove emotsyonalnoho intellekta [Emotional Leadership: Learning to Lead with Emotional Intelligence]. M.: Alpina Publisher. 
6. Fernández-Gámez, M.A., Torroba-Díaz, M., Molina-Gómez, J. A. (2021). Study of the emotional intelligence and personality traits of university finance students. Education Sciences. (11(1):25). DOI:10.3390/educsci11010025

7. Kataloh osvitnikh posluh Lvivskoi politekhniky. Napriam pidhotovky «Menedzhment» [Catalogue of educational services of Lviv Polytechnic. Management direction of training] URL: http://edu.lp.edu.ua/napryamy/6030601-menedzhment [in Ukrainian]

8. Ruel Ch. Teaching emotional intelligence to students. Wiley. URL: https://www.wiley.com/network/instructors-students/teaching-strategies/teaching-emotionalintelligence-to-students

9. Nosenko, E. \& Chetveryk-Burchak A. (2014). Posibnyk do vyvchennia kursu «Teoriia emotsiinoho intelektu» [Manual of studying Theory of Emotional Intelligence course]. Dnipropetrovsk [in Ukrainian].

10. Discover your level of EI. Global Leadership Foundation. URL: http://globalleadershipfoundation.com/geit/eitest.html 